\title{
Border Support Networks: \\ Migrant Caravans, US Activism and Social Network Analysis
}

\author{
Authors: \\ Guadalupe Correa-Cabrera \\ Cindy Gómez-Schempp \\ Naoru Koizumi \\ Rajendra G. Kulkarni
}

\author{
Corresponding author: \\ Guadalupe Correa-Cabrera \\ Associate Professor \\ George Mason University \\ Schar School of Policy and Government \\ Van Metre Hall, Room 676 \\ 3351 Fairfax Drive \\ Arlington, VA 22201 \\ gcorreac@gmu.edu
}

\section{DRAFT}

Please do not quote, cite, reproduce, or distribute without permission of the author

Paper prepared for delivery at the

2020 Annual Meeting of the American Political Science Association (APSA)

116th APSA Annual Meeting

Social Networks and Political Mobilization in the Trump Era

Sunday, September 13

2:00 to 3:30pm MDT (4:00 to 5:30pm EDT) 


\title{
Border Support Networks: Migrant Caravans, US Activism and Social Network Analysis
}

\author{
Authors: \\ Guadalupe Correa-Cabrera \\ Cindy Gómez-Schempp \\ Naoru Koizumi \\ Rajendra G. Kulkarni
}

\begin{abstract}
The present article applies social network analysis (SNA) to understand the formation of migrant caravans that originate in Central America and transit throughout Mexico, the Native American protests against the Dakota Access pipeline in Standing Rock, and other related social movements. This analysis explains new forms of activism in the Americas against US restrictive immigration policies and border security measures, as well as their link to other phenomena of seemingly different nature-including political-electoral ones.
\end{abstract}

KEYWORDS: Social Network Analysis, migrant caravans, Standing Rock, social movements 


\section{CONTRIBUTORS}

Guadalupe Correa-Cabrera (Ph.D. in Political Science, The New School for Social Research) is Associate Professor at the Schar School of Policy and Government, George Mason University. Her areas of expertise are Mexico-US border relations, drug trafficking, organized crime, irregular migration, human trafficking and migrant smuggling. She is Past President of the Association for Borderlands Studies (ABS); Global Fellow at the Woodrow Wilson International Center for Scholars, and Non-resident Scholar at the Baker Institute's Mexico Center (Rice University). She is also co-editor of the International Studies Perspectives (ISP) journal.

Cindy Azucena Gómez-Schempp is radio host of A Mexican Crossing Lines, station manager for newly formed low power FM radio station KPPP FM, Board Vice President of the People's Press Project (PPP), former Editor-in-chief of the High Plains Reader and a culture and language educator. She is a Mexican-American journalist with a background as paralegal, writer, non-profit executive director, human rights activist, community organizer, social service worker, court translator, youth worker, juvenile court tracker, culture language and nutrition educator.

Naoru Koizumi (PhD in Regional Science, University of Pennsylvania, 2002; PhD in Environmental and Preventive Medicine, Hyogo College of Medicine, Japan, 2005) is Director of Research and Professor at George Mason University. She specializes in health policies, particularly in the fields of chronic illnesses. Her research focuses on the applications of various quantitative tools, such as statistics, Geographic Information Systems (GIS), simulation and mathematical optimization to analyze various policy questions related to medical issues and other social science areas.

Rajendra G. Kulkarni (M.S. Computer Science, George Mason University, 1994) is researcher at the Schar School of Policy and Government, George Mason University has more than fifteen years of experience in interdisciplinary individual and team research with focus on quantitative, visual and network analytics and modeling. His current areas of expertise and interest include: blockchain models of regions; remittances and cross-border payments with Libra type stable-coin cryptocurrencies; deep neural nets for region identification, and big data network analytics to model spatio-temporal sensing of activity patterns. 


\section{INTRODUCTION}

"Migrant caravans" that were formed in recent years have greatly modified the dynamics of irregular or undocumented migration, the demographic composition of migratory flows and the behavior of migrant smuggling networks in the Americas. These phenomena have also had a great impact on the perception of public opinion, in both the United States and Mexico, regarding issues that have generated huge polarization in the recent era, such as immigration enforcement and US-Mexico border security cooperation (Felter and Laub 2019). It is important to highlight that, presently, issues related to irregular or undocumented immigration, US immigration policy and President Donald Trump's proposal to build a border wall are at the center of the political-electoral debate in the United States, which is why the analysis of these phenomena is fundamental.

The aim of this research is to explain the formation of migrant caravans with a focus on their organizers and the groups they represent. The formation of migrant caravans does not appear to be a purely spontaneous or "organic" phenomenon, that is, simply derived from structural phenomena or traditional pull and push factors. In fact, a deeper analysis of these recent episodes of mass migrations suggests the existence of external actors and factors that would induce such mobilizations. Various opinions both in Mexico and the United Statesincluding those of government authorities in both countries-highlight direct involvement of different individuals or groups (e.g. the organization "Pueblo Sin Fronteras") for having directly supported the formation, development and transportation of migrant caravans (CorreaCabrera and Bersin 2018).

The caravan phenomenon and its effects on migratory flows have, in turn, had a fundamental impact on recent changes to immigration and asylum laws in the United States (still subject to judicial review), while influencing the new actions and policies designed and

\footnotetext{
${ }^{1}$ See Linthicum (2018).
} 
implemented to strengthen border security in both the United States and Mexico. These phenomena have also had a decisive effect on the American political debate and remained as key themes in the presidential election debates of the year 2020. On the other hand, it is less clear, but not unlikely, that the phenomenon of migrant caravans and the evolution of the support network for these mass migration movements are related to complex issues of geopolitics (Yaworsky, et al. 2020).

It is worth noting that some of the participants in these events had a direct presenceor maintain links with people or groups that participated - in the mobilization against the construction of the Dakota Access pipeline in Standing Rock, North Dakota (\#NDAPL) in the years 2016-2017. These activists — many of them of US citizens — are part of a larger network apparently related to progressive movements in the United States and other regions of the continent (even in other parts of the world). They also relate perhaps to radical groups and NGOs whose function is not yet clear and could be related to political-electoral processes in the United States.

The first part of this work provides background information on the caravanization of undocumented migration and its main organizers, some of which are directly or indirectly linked to the protests in Standing Rock. This section explains the relationship between the participants in the two movements and their logics of operation. In order to understand these links, as well as the interactions between the main actors participating in these two episodes of social mobilization, this work applies social network analysis (SNA) and establishes some key categories in order to understand the role of each actor and organization in the migrant caravans support network and related social movements.

\section{BACKGROUND}


In recent years, important changes have been observed in the dynamics of irregular and undocumented migration from Central America and other parts of the world to the United States, as well as in the origin and sociodemographic composition of the migrant population that crosses the southern border of Mexico towards the north of the continent. Migrant caravans and the very significant increase in the number of so-called "unaccompanied minors" are part of this great change, in which the search for asylum becomes a resource increasingly used by migrant or refugee populations that begin to emigrate en masse and whose composition is changing to include a greater number of women and children (Hallock, Ruiz Soto and Fix 2018).

Key actors have accompanied and facilitated the transit of migrant children and families to the border with the United States in a seemingly concerted and well-organized manner in recent years. The caravans are a recent phenomenon that begin to form properly within the framework of the so-called "Vía Crucis migrante" (migrant Way of the Cross), ${ }^{2}$ which was simply a representation of the dangerous journey that migrants experience in their passage through Mexico to achieve the "American dream." This caravan was organized by representatives of the Catholic Church, along with some activists and the phenomenon spread and reproduced in the years that followed. New forms of mass migration, as well as the generalization of asylum petitions by migrant populations crossing though Mexico's southern border - and originating from different countries inside and outside the continent - were also supported, and sometimes accompanied and promoted by some NGOs (such as the organization Pueblo Sin Fronteras). It is also important to recognize the fundamental role of human smugglers, who in exchange for a fee (sometimes a very substantial one), facilitate these new processes of "human mobility."

\footnotetext{
${ }^{2}$ Vía Crucis represents the Stations of the Cross depicting the trials of Jesus Christ as he was about to be crucified.
} 
This new type of migration flows and the significant growth in asylum applications became visible in 2013 and began to gain notoriety in the summer of 2014 with the so-called "crisis of unaccompanied migrant children" (Solalinde and Correa-Cabrera 2019). But it was not until 2018 when the caravan phenomenon reaches worldwide notoriety and international coverage, while becoming widespread by offering a viable option for those who wanted to travel more safely through Mexican territory and did not have sufficient resources to pay a human smuggler (also called coyote) or some organized crime group who could facilitate the journey in exchange for a fairly high fee (Sieff 2018). For a few months, migrant caravans became quite popular as they were considered to offer a real possibility for migrants to reach the United States.

In times of enormous social and political polarization in the United States with regard to the themes of migration and border security - and in the context of an administration that maintains the discourse of the construction of a border wall as a political-electoral strategy and an emblematic issue heading into the presidential election of 2020 - the issue of migrant caravans remains a key one. The images of a humanitarian crisis at the border and the perceived invasion of migrants that President Trump had so often prophesied, became a reality, or rather, were perceived as reality by a part of the US public opinion. Similarly, members of the Democratic Party utilized images of the caravan to make a fundamental criticism against Trump's migration and asylum policy.

\section{The migrant caravan support network}

Communication during the peak of the caravan at the end of 2018 was very effective and seemed to be part of an operation designed in advance and organized for specific purposes. On the one hand, "the images of people rushing the border, throwing rocks at Border Patrol agents and being repulsed with tear gas, against a background of concertina wire installed by the U.S. 
military," seemed to "foster the impression sought by President Trump" (Correa-Cabrera and Bersin 2018). On the other hand, the treatment of migrants and asylum seekers by the US authorities was capitalized by the Democratic Party, its supporters and representatives, as well as by those within the Republican Party who wish to see the end of Trump's administration and dominance.

It is not clear at first glance who was behind these mass mobilizations, however, everything seems to indicate that these phenomena are not entirely spontaneous and that they respond to agendas of specific actors. The new theories of social movements can better explain these massive migrations (Jenkins 1983; Buechler 1995; McAdam, McCarthy y Zald, eds. 1996; Tarrow 1998) in a context where country conditions (the thrust and attraction factors of migration) do not change too much, but where there seem to be substantial material resources, concrete political opportunities (such as the mid-term elections in the United States), wellarticulated leadership and effective framing processes-including the effective use of formal means of communication and social networks to report on these phenomena, even internationally.

It is important to note that the formation of migrant caravans, or recently observed mass migration movements, does not only respond to the aforementioned factors, but are also explained by the existence of structural causes - that is, they have a clear organic or spontaneous component. Many of these people experience hunger, misery or extreme violence that displaces them from their original territories. On the other hand, it is undeniable that many of those who travel by caravan find in this mechanism a less expensive and a safer way to make a trip to the United States (Álvarez 2018; Carlsen 2018; Sieff 2018). These types of components that can be considered organic or spontaneous, can effectively produce protests, strikes, electoral changes and mass emigrations. Notwithstanding the last, it is difficult to imagine that caravans of migrants of similar dimensions to the one that was formed in October 
of 2018 — and that remained united and growing over hundreds of miles — did not involve the participation of external actors that facilitated the process.

In sum, migrant caravans are organized in a context under which important groups of people find compelling reasons to join them. However, these mobilizations do not seem to be entirely spontaneous. Considering the logics of social movement theories (Craig 1983; Buechler 1995; McAdam, McCarthy y Zald, eds. 1996; Tarrow 1998), in addition to the particular conditions under which these mass migrations originated, it is possible to formulate a series of relevant questions: Why do these phenomena occur at this precise moment? The structural causes of migration from the so-called Central American Northern Triangle (Guatemala, Honduras and El Salvador) have been present for several years. However, these phenomena are relatively new. What has happened that has changed the context?

Why do people join caravans instead of looking for more conventional ways to cross Mexico into the United States? As stated earlier, there are reasons why caravan migration can be attractive: it reduces travel costs from Central America or the southern border of Mexico and eliminates some risks of traveling in the company of so-called coyotes or humantraffickers—which on several occasions have been linked to organized crime (Álvarez 2018; Carlsen 2018; Sieff 2018; Slack y Campbell 2016; UNODC 2010; Vogt 2013). Nevertheless, there are limitations to this logic and some key questions need to be answered: What do those people who participate in these movements think will happen once they reach the US-Mexico border? Considering actual border security policies and restrictions on irregular migration put in place by the current administration in the United States, why wouldn't these people travel on known clandestine routes and prefer, instead, to be part of a very visible group (because of their large size) and increased scrutiny by the authorities?

In this specific context, if the caravans are organized or even encouraged in a way, who are the organizers and what are their objectives or possible agendas? Why do they participate 
and with whom? The present analysis is a preliminary attempt to answer these questions. This exercise will focus on the actors that accompany, support and incite recent mass migrations through migrant caravans. The national or transnational origin of these actors will be analyzed, as well as their background and forms of operation. The main aim of the present research is to identify and analyze some of the main organizers of migrant caravans and related social movements, their specific role in the process of formation and accompaniment of these social mobilizations, as well as the organizations to which they belong to.

\section{METHODOLOGY}

\section{Social Network Analysis}

In order to answer the aforementioned questions, it is essential to analyze in detail the composition of the network providing support to the migrant caravans and individuals/families seeking asylum in the United States. The present analysis makes use of a methodological tool known as social network analysis (SNA), through which the key actors of the caravan support network are identified and the links between them are analyzed. In other words, through this exercise we will locate the central nodes, and will identify the inter-connections of actors within the caravan support network, as well as the links between these actors and those participating in related social movements.

In order to apply SNA to the group of actors that have supported migrant caravans and related mobilizations in our continent, a preliminary database containing these actors and their interactions was constructed with information gathered from: 1) participant observation in the field (in the border cities of Tijuana-San Diego, Ciudad Juárez-El Paso and the Rio Grande Valley); 2) content analysis of media coverage on the caravan phenomenon and irregular migration, and 3) data collection of interactions between actors in social media or electronic communication sites (through web scraping or web data extraction). An attempt was also made 
to identify the main actors that participated in the accompaniment and promotion of the migrant caravan-made visible internationally at the end of 2018 - as well as in the organization of other activities related to these groups and other social movements.

As part of this effort, some of the key people who organized, promoted and/or accompanied the large migrant caravan that began to be formed in October 2018 were identified. They communicate through specific electronic platforms (most of the time through Facebook, WhatsApp, Twitter and Instagram accounts). We focus primarily on the use of the communication network via Facebook called \#BorderSupportNetwork (BSN)—before called "Asylum Seekers (Caravan) Support Network" or simply "Caravan Support Network" that is closely related to the "Border Liberation Front" and with platforms or movements such as \#\#AbolishICE and \#OccupyICE.

\section{The Network since Standing Rock}

The main administrators and active participants in this platform are mostly originated in the United States and some of them were also identified as key actors in organizing mass protests in the Sioux reservation of Standing Rock in North Dakota (Gomez-Schempp 2018) ${ }^{3}$. The protestors (using the hashtag \#NODAPL) were opposed to the construction of the Dakota Access pipeline that would pass through Native American lands. Many of them called themselves "water protectors," because they were fighting the construction of energy infrastructure that could endanger drinking water in Standing Rock (Estes 2019; Estes and Dhillon, eds. 2019).

As part of a legitimate mission to defend the rights of Native American peoples, Standing Rock activists managed to raise millions of dollars in donations. These organizers caused very violent clashes with the authorities, which came at the expense of group cohesion and brought increased scrutiny on the movement. Although large financial resources and

\footnotetext{
${ }^{3}$ This reservation extends into South Dakota as well.
} 
various groups of alleged defenders of Native American peoples were mobilized—including veterans, activists of various kinds, anti-fascist groups and other protest groups - the desired objective was not achieved. In the end, the pipeline was built, the camps (where resistance was carried out) disintegrated and the organizers of the protests ceased their attempts to protect the water and lands of Native Americans peoples in Standing Rock (see Estes 2019 and Estes and Dhillon, eds. 2019).

It should be noted that in order to carry out their activities and achieve their objectives, Standing Rock activists collected large funds, many of them through electronic collective financing platforms, or crowdfunding (Venmo.com, GoFundMe.com). It has not been possible to clearly determine the ultimate recipients of all the millions of dollars in donations channeled to the activist groups that supported the Standing Rock protests. There are serious doubts regarding the use of an important part of these resources (Brewer 2018, Funes 2018).

The mobilizations against the construction of the Dakota Access pipeline culminated in 2017 and this great infrastructure project was completed in April of that year. Some of the most relevant Standing Rock activists quickly changed residence ${ }^{4}$ and set out to organize protest demonstrations in other regions of the country. Others moved to provide "humanitarian" support after natural disasters such as Hurricane Maria in Puerto Rico in September 2017. Surprisingly, some of the key figures who were in Standing Rock appeared in Mexico providing direct support to the migrant caravan in late 2018. Their role was leading in resistance actions and confrontation with the authorities, especially in Tijuana (Baja California) and other parts of the U.S.-Mexico border area (Yaworsky, et al. 2020). Their actions and strategies have been similar in nature to those recorded in Standing Rock.

\footnotetext{
${ }^{4}$ Many activists stated they were homeless because they sold everything to come live at Standing Rock. Afterward these activists went from camp to camp or city to city living out of cars, hotels and couches of supporters.
} 
Some claim that these protesters infiltrated the caravan with possible political and fundraising agendas (Gomez-Schempp 2018). According to this argument, there is a possibility that these actors actually operate as professional activists and that they are experts in promoting protests without regard to the ideology or the issue. Some of them participated in 2016 and early 2017 as water protectors and are now part of the support network for migrant caravans and those seeking asylum in the United States.

It is worth noting that the present work does not refer to all networks that support indigenous groups or provide protection to migrant communities in transit. This analysis focus exclusively on specific actors who seem to operate like 'professional activists'. In more recent times, these activists have also participated in the mobilizations against: the construction of the border wall; the existence of detention centers and the immigration policies that President Donald Trump's administration has advanced. In general, it is possible to raise the idea that the participation of these actors is not completely spontaneous, but responds to alternative political or economic agendas.

\section{A BORDER SUPPORT NETWORK (BSN)}

This section applies SNA to a small sample that is part of a larger database integrated with information collected beginning in August 2016. This database was constructed by constantly monitoring the activities of specific actors (part of the networks referred to above) in communication media and various electronic media platforms. Here is a small sample of the network, composed of 21 key actors or people who participated in or supported two specific social movements: Standing Rock protests and the support network for migrant caravans. The objective of this exercise is to determine the relative importance of these actors in the two networks (considering that some of them represent a particular organization), as well as the relationship and degree of cohesion between them. We try to explain the proximity or linkage 
of these activists (or 'professional' activists) with the agendas of other actors outside the network but who benefit from the effects or activities of the network. In short, through the SNA, the central nodes and the links between them will be identified.

The basis of this analysis was a detailed follow-up of the activities and interactions of key participants in the network called \#BorderSupportNetwork (BSN). The selection of 21 key actors in this network (some of which represent more specific groups of activists or NGOs) was carried out after a timely follow-up on social networks that identifies the protagonists or the main organizers of the Standing Rock protests and the support network for migrant caravans (now support network for border activism with an agenda against Trump and his policies such as the construction of the border wall). The creation of this database required social intelligence work carried out for almost three years (starting in August 2016) that involved several people collecting and documenting information through social networks.

\section{The network and a presentation at Antioch College}

Another criterion for selecting the sample of actors for this SNA has to do with the operation of the network itself. The selected actors represent the main functional categories of this network of self-proclaimed human rights activists or defenders. In other words, an attempt was made to include in the sample a representative of each of the main groups that apparently formed the network. Each group fulfills a function that will be represented by a specific person in the present analysis. To make this selection, the activists' strategy was analyzed through an explanation they gave at Antioch College in Yellow Springs, Ohio. ${ }^{5}$

In December 2018, some members of the BSN visited this institution in order to recruit volunteers as a part of completing their mission and resistance actions. Thus, in statements made on a radio program and elsewhere during the visit, they explained the operation of the

\footnotetext{
${ }^{5}$ This information can be found in the following link: https://www.wyso.org/post/antioch-word-explores-bordersupport-network.
} 
network and mentioned the main groups that would form it, as well as the functions of each one. There were three objectives: 1) education, 2) resistance actions, and 3) support for migration. All this was based on their interpretation of what is known as the "Prophecy of the Eagle and the Condor" which is a belief of some indigenous cultures about a world transformation that would be achieved when the indigenous people of the North-represented by the eagle — unite with the indigenous people of the South — represented by the condor - to achieve common goals. $^{6}$

Similar ideas of the indigenous nations of the hemisphere were also used in the Standing Rock mobilizations, in which various figures who are now part of the Caravan/Border Support Network also participated. Under this notion, the activists propose to provide support so that migrants "know their rights", through their so-called education or legal support schemes. They also propose participation in resistance actions ("aggressive, but not violent" according to them) at the border and other places, and finally they design a very well organized campaign to support migrants who come from the south of the continent.

In the presentations that the members of the BSN gave at Antioch College, it is explained in detail what each of the three parts of the strategy consists of, in addition to how the necessary funds would be obtained to achieve the stated objectives (see Figure 1). At the same time, specific names of some people and organizations that would participate in each of the aforementioned activities were provided. Finally, there was talk of the creation of "villages of radical existence", which can be interpreted as the establishment of camps to resist the construction of the border wall, an even greater reinforcement of border security and

\footnotetext{
${ }^{6}$ In the link provided in the previous footnote, one can listen to the interview done with Lilith Sinclair, a BSN member, who provided details about this network and its project. The objective of Sinclair and other members of the network in Antioch College was to "meet with members of the community interested in helping people at the U.S.-Mexico border." The activist talked about the BSN's project, their actions to resist the construction of the border wall, as well as what potential volunteers affiliated with Antioch College could do to support this project.
} 
restrictions on entry to the United States of migrants seeking asylum, from the south of the continent.

\section{Figure 1: The Border Support Network}

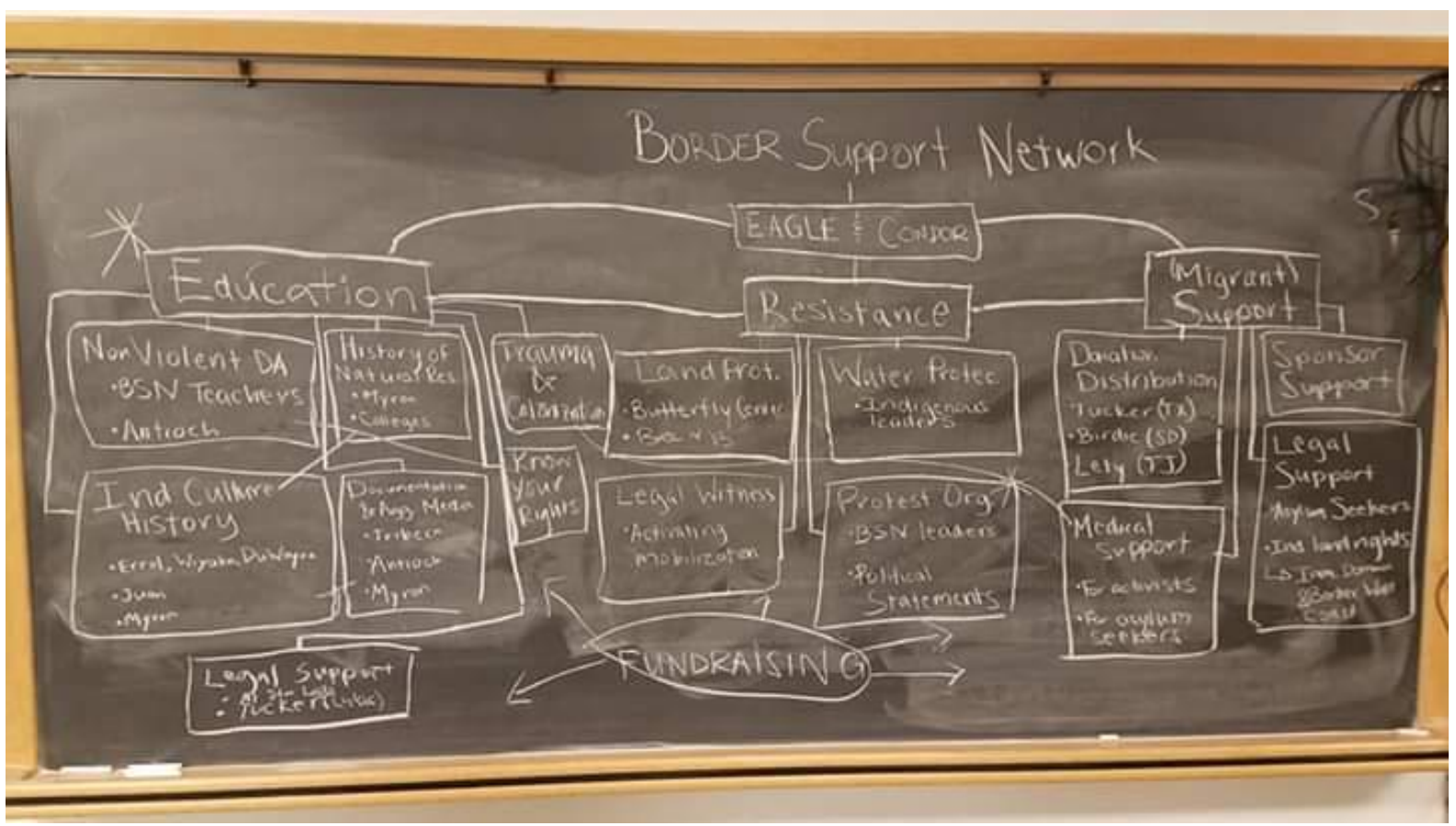

Sources: Members of the BSN in Antioch College, Yellow Springs, Ohio, 2018.

It should be noted that some of the key actors who founded and that are part of the BSN had directly participated in or supported the Standing Rock mobilizations. Other members of this network appear to have some degree of relationship with activists linked to some extent with Standing Rock and other related movements that had their origin in protests to symbolically occupy Wall Street (Occupy Wall Street), as well as the movements to occupy or abolish Immigration and Customs Enforcement, or ICE, (Abolish ICE and Occupy ICE), the Women's March and Code Pink. ${ }^{7}$ In addition to these actors, others were selected with ties to the network of activists or people who participate directly in the protests in other ways, either by providing funds or by systematically carrying out media coverage for their causes. These other actors include politicians, journalists, personalities from the entertainment industry, as

\footnotetext{
7 On these movements and some of their activities and communications see: https://www.facebook.com/AbolishICEPortland/; $\quad$ https://www.facebook.com/occupyice/; https://twitter.com/occupyicepdx?lang=en; https://womensmarch.com/; https://www.codepink.org/.
} 
well as influential communicators ("influencers") in social networks. These relationships were established through timely monitoring in social networks and media since the Standing Rock protests began in 2016 .

\section{1 actors}

Timely follow-up of communications between actors and their mentions in social networks and formal media allowed us to preliminarily establish a preliminary network and delineate a classification of actors. In this exercise, we chose 21 names of the people we initially considered some of the most important in the network. Each person represents a specific group of actors, an organization, an activity, or a key leadership within the network. Each plays a fundamental role, considering the explanation given to us by members of the BSN at Antioch College. The list is made up of the following people (name and affiliation):

1. $\quad$ Evan K Duke III - BSN and Antifa

2. Lilith Sinclair / Kiara Horsely - BSN, Antifa and \#OccupyICE

3. Myron Dewey - Digital Smoke Signals

4. Wiyaka Eagleman - Errol Medicine

5. Juan B. Mancias - Carrizo/Comecrudo Tribe of Texas

6. Vanessa Dundon (SiouxZ Dezbah) - Missing Flowers: Missing and Murdered Indigenous Women and Men

7. Mark Lane - Minority Humanitarian Foundation

8. $\quad$ Mohamed M. Elnakib - San Diego Rapid Response Network

9. Nicole Ramos - Al Otro Lado

10. Anakai/Nakay/Roberto Flotte ("Pitaya Queen") - Diversidad Sin Fronteras

11. Alex Mensing - Pueblo Sin Fronteras

12. Birdie Gutierrez - Bridges of Love Across Borders

13. Shane Parmely -San Diego School District

14. Linda Sarsour - Women's March

15. Doug McLean - Indigenous Life Movement

16. Rob Wilson - Rob Wilson Photography

17. Winnie Wong - People for Bernie and Women's March

18. Jay Ponti - \#BankExit

19. Frances Fisher -Hollywood actress

20. Desiree Kane - Pollen Nation Magazine

21. Paola Mendoza - Soze Agency and Women's March

\section{Classification of actors}

According to the affiliation and activities of these 21 people, four categories were established that illustrate the generic functions of each actor (see Figure 2). This allows us to better 
understand the operation of the network, which goes beyond the resistance actions at the border and is related to other social movements such as Standing Rock or the Women's March in the United States. Thus, we classify the list of actors into four categories: i) the main organizers or "founding members" who design the ideology of the movement and its communication and resistance strategies; ii) those who provide support or assistance to vulnerable groups and secure funds and donations to specify and coordinate altruistic activities; iii) the so-called "messengers" that represent all the groups in the network, design the general communication strategy and organize (from above) the protests themselves, and iv) the group of "influential communicators" (influencers), that is, the group of actors or personalities in social networks or the entertainment world that ultimately give legitimacy and provide cohesion to the movement.

\section{Figure 2: Classification of Actors}

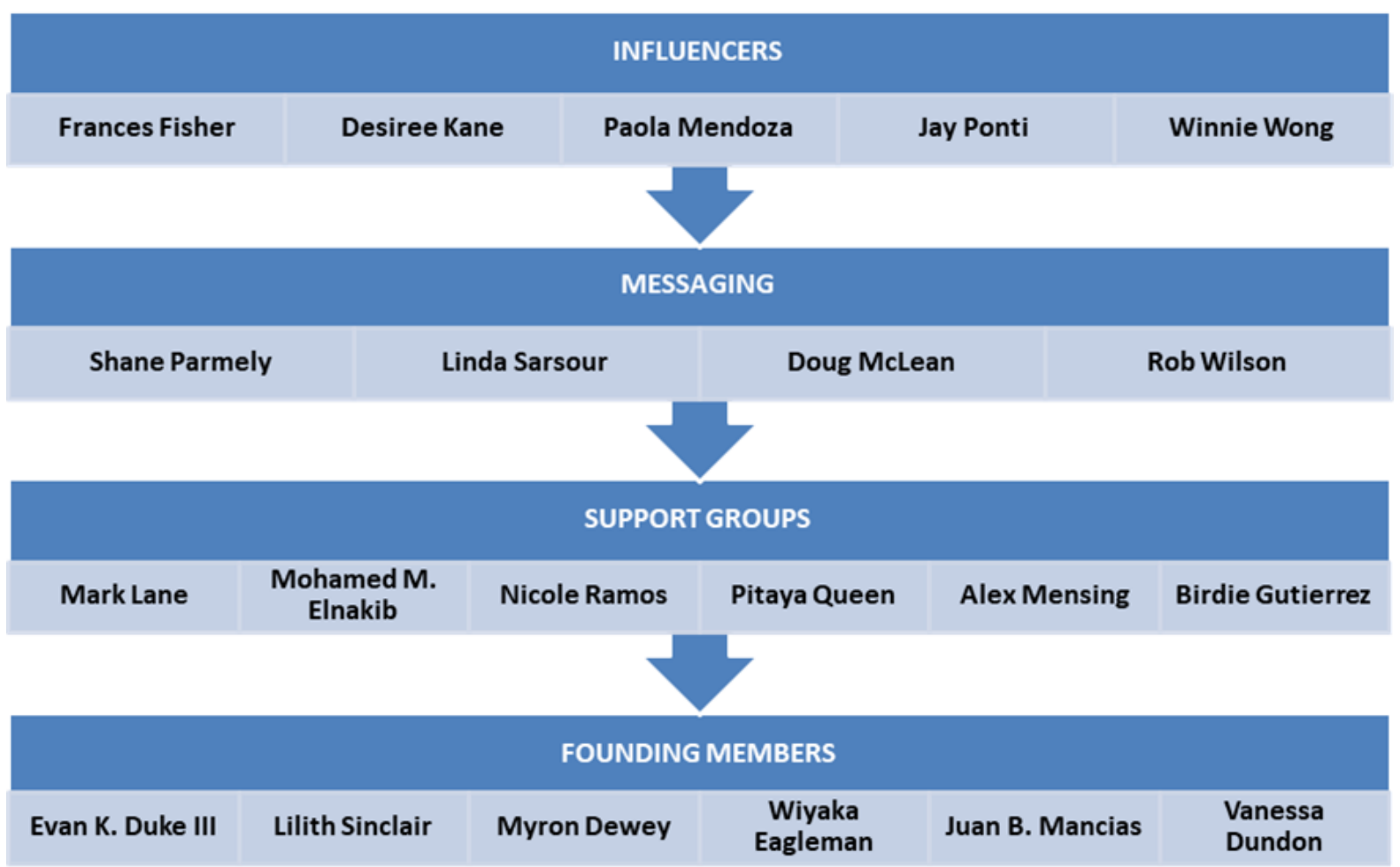

\section{Founding members}

Members of this group are represented by people such as: 1) Evan K Duke III of Veterans Stand for Standing Rock, who identifies with anarchist, Marxist and anti-fascist groups 
(Antifa); 2) Lilith Sinclair (real name "Kiara Horsley"), identified with sex workers, anarchist groups and Antifa; 3) Myron Dewey ${ }^{8}$, activist, journalist, founder of the Digital Smoke Signals news platform, drone documentary filmmaker and pilot affiliated with Drone Pilots from Standing Rock; 4) Wiyaka Eagleman of the Indigenous Environmental Network and Errol Medicine, who actively participated in Standing Rock; 5) Juan B Mancias ${ }^{9}$, leader of the unrecognized Carrizo/Comecrudo Tribe of Texas, who also participated in Standing Rock and is now very active in protests against the construction of the border wall; and 6) Vanessa Dundon (also known as Sioux Z. Dezbah) ${ }^{10}$ of the group Missing Flowers: Missing Murdered Indigenous Women and Men.

Those we call "founding members" could be considered the "foot soldiers" of the movement. They are the most active characters, visible faces, or "boots on the ground" in the social movements described here. These actors lead the marches and organize protests of all kinds, hunger strikes, assemblies, among other resistance activities. In addition, some of them have come to directly support the caravans. ${ }^{11}$ These are the people in charge of establishing the camps, moving donations and people along the migration routes and positioning themselves in front of the protests. An in-depth analysis of the actions of these "foot soldiers" shows how they tend to imitate and attempt to represent genuine groups of activists and original resistance movements of environmentalists, veteran groups, and other vulnerable populations, such as native peoples or Native American groups (Yaworsky, et al. 2020).

These leaders are closely linked to the so-called influencers who, as the name implies, have great influence in the media and in particular in social networks. In addition, they widely

\footnotetext{
${ }^{8}$ Dewey is married to Deborah Parker, an important political influence in the Democratic Party.

${ }^{9}$ Mancias is closely affiliated to the American Indian Movement (AIM) and Society of Native Nations, among other groups providing 'security' for indigenous movements.

${ }^{10}$ Vanessa Dundon also participated in Standing Rock being one of the severely injured (lost vision in her eye) during a seemingly staged confrontation between protesters and law enforcement on November 20, 2016.

${ }^{11}$ Evan K. Duke III, for example, was present in the city of Tijuana supporting the big migrant caravan formed in the last months of 2018 .
} 
disseminate the results of the movement and determine the direction of some key activities, making them visible and communicating them virally. The founding members present themselves as moral leaders, or as representatives of the identity of indigenous peoples or indigenous nations (such as the not federally recognized Carrizo/Comecrudo Tribe of Texas), as well as some political ideologies and movements of a rather liberal and even radical nature (like Antifa). These identities and their relationship with current power groups largely dictate the direction of the work of the founding members.

The so-called "founding members" in this scheme establish the guidelines for the organization of events, marches, protest or resistance movements and press stories that are beneficial to their movement. At the same time, they define the tone of the narrative and the focus of its allies in the media. Many times they position themselves as the main subject or the protagonists of the media stories that they themselves help to narrate.

\section{Support Groups}

The second category of actors presented here is formed by the people, groups of people or key NGOs that do humanitarian work. Among these groups or actors we have, for example,: 7) Mark Lane, who heads Minority Humanitarian Foundation, was a content producer for The Young Turks (TYT or Young Turks), co-directs the Caritas shelter and is associated with organizations such as Diversity Without Borders (headed by the LGBTQ caravan), Yes We Can, This Is About Humanity, Families Belong Together; 8) Mohamed M. Elnakib, linked to the San Diego Rapid Response Network (SRRN), March for Our Lives, No Muslim Ban, Black Lives Matter, Abolish ICE and the Women's March; 9) Nicole Ramos of the organization Al Otro Lado (On the Other Side), and linked to Immigrant Defenders Law Center, Innovation Law Lab, National Lawyers Guild, Rise to Reunite, Tijuana Food Not Bombs, Enclave Caracol, New Sanctuary Coalition, and Migrant Welcome Committee East Bay, among other organizations; 10) Pitaya Queen or Anakai / Roberto Flotte of Diversity Without Borders 
(which seems to be part of a network 'with surname' "Without Borders" such as: Butterflies Without Borders, Solidarity Without Borders, Home Without Borders, etc.), who also relates to 'Chinga la Migra' and Pink and Black Anarchists; 11) Alex Mensing of the organization Pueblo Sin Fronteras, who is linked to the BSN, and is close to groups such as Freedom for Immigrants, Border Liberation Front, Border Angels, Migrant Culture, Enclave Caracol, among others; and 12) Birdie Gutierrez, who heads the Bridges of Love Across Borders organization and the Caritas shelter, in addition to interacting with groups such as The Flower of Resistance, Women's Medicine, SRRN, BSN, Jewish Family Services and Enclave Caracol.

People within this category of actors function as the links between the foot soldiers or the founding members and the other two groups in this classification of actors: messengers and influencers. They are the face of civil society organizations and recently formed campaigns to support migrants. They validate the actions of key activists or founding members, while validating each other as 'human rights defenders'. In this group we find veterans, caravan escorts and artists who receive awards for their 'humanitarian' work.

In general, we include in this category altruistic groups that need financing and support to continue their seemingly humanitarian functions or work. They represent the "elected" among the members of the BSN to recruit volunteers and receive funding. Under this scheme, renowned activists, along with media, influencers and other founding members, are expected to support these alleged defenders and their organizations, often excluding humanitarian action groups that had enjoyed great recognition in the past and that have extensive experience. This group is formed by activists who are willing to take significant risks and also by aggressive communicators who viralize their messages in formal and informal media through messengers and influencers. Many times, these messages have little to do with reality.

\section{Messengers}


This group is represented by: 13) Shane Parmely, educator of the San Diego School District, who relates to SRRN, Minority Humanitarian Foundation, Bridges of Love Across Borders, Hungry4Freedom, American Babylon, Families Belong Together and California Educators Rising; 14) Linda Sarsour, one of the main organizers of the Women's March, Immigrant Movement International, linked to Our Revolution, The People for Bernie Sanders, Democratic Socialists of America, the movement to advance the rights of the Muslim rights group MPowerChange, Generation Justice San Diego and Indigenous Peoples March; 15) Doug McLean, who participated in Standing Rock in the protest against the pipeline on the side of the Water Protectors and is the co-founder of the Indigenous Life Movement social media platform, Veterans Respond, Water is Life Movement, RezPect, Our Waters, Now This, and Sanctuary Caravan; and 16) Rob Wilson, a photographer by profession (in Rob Wilson Photography) who participated in Standing Rock and captured images of the migrant caravan that arrived at Playas de Tijuana at the end of 2018 — was also present at the shelter "Contra Viento Y Marea" and has been linked to the Hecate Society, Its Going Down, Veterans Respond, Veterans for Peace, Digital Smoke Signals, Pueblo sin Fronteras, Voices Without Borders, Enclave Caracol and YES! Magazine.

The actors in this category remain in close contact with the media, politicians and political parties at the state, local and federal levels. These so-called "messengers" represent specific media platforms and, on several occasions, they are themselves photographers or reporters of the topics they are interested in covering. For example, in the case of migrant caravans, the messengers were responsible for covering the facts by promoting the request for asylum in the United States and mass migration, in addition to advancing a fundamental criticism of the Mexican and US administrations for the alleged violation of the rights of migrants. All this serves the agenda of the entire network. These messengers not only control 
the narrative in the media, but they design the message, plan its dissemination and choose target audiences.

These types of actors also initiate the information chains that will be communicated through social networks via hashtags. On the issue of migration, for example, they generate tags such as: \#NoMuslimBan, \#ImpeachNow, \#AbolishICE, \#ClimateRefugee, \#NoBorderNoWall, among others. In this category, the roles of the actors are confused or exchanged between those of human rights activists/defenders and those of creators in media/communicators/messengers. These people influence public opinion through their political contacts. In addition, they actively participate in the media to place organizations or activists close to their group at the center of the spotlight, so that they themselves can receive funding and support. In other words, the messengers ensure support for the group of highprofile activists who do the work with the communities.

\section{Influencers}

This group includes actors, musicians, personalities from the entertainment industry and political fans with large numbers of social media followers and powerful influence with political leaders. In this category are: 17) Winnie Wong, political activist, co-founder of The People for Bernie Sanders campaign and advisor to the Women's March; ${ }^{12}$ 18) Jay Ponti, activist $^{13}$ and co-founder (along with actress Susan Sarandon) of the \#BankExit campaign as well as (along with Vanessa Dundon co-founder of Missing Flowers, Missing and Murdered Indigenous Women and Men); 19) actress Frances Fisher, who is associated with MoveOn.org ${ }^{14}$ and is close to groups such as Confluence Documentary, \#NoDAPL or the Standing Rock

\footnotetext{
${ }^{12}$ Wong has been related to groups or movements such as Occupy Wall Street, \#AsianAmericansForBernie, Brand New Congress, ActBlue, Justice Democrats, Democratic Socialists of America, \#AbolishICE and TYT, among others.

${ }^{13}$ Ponti is connected with diverse groups or networks such as \#OccupyInauguration, \#BlackLivesMatter, Our Resistance, Tulsi2020, The People for Bernie Sanders, Activate Now and TYT.

${ }^{14}$ Moveon.org (previously called Censure and Move on) is a movement or Political Action Committee (PAC), which promotes social causes and has help to raise substantial funds to support political campaigns of liberal (or left-wing) candidates.
} 
protetest, \#WaterIsLife, the \#BankExit campaig ${ }^{15}$, \#ThePeoplesOath, Our Revolution, \#MeTooMarch and Code Pink; 20) Desiree Kane, multimedia journalist, producer of live media events, co-founder and editor/director of digital content in Pollen Nation Magazine and the promoter of the film Akicita: The Battle of Standing Rock; ${ }^{16}$ and 21) Paola Mendoza, film director, activist and writer, co-founder of The Soze Agency, which is linked to the Women's March, This Is About Humanity, Go Campaign, Neighborhood Unitarian Universalist Church and Act Blue.

The so-called influencers mark the trends in content and information that circulates in formal and informal media and are celebrities or gurus themselves. They mobilize hundreds of thousands (or perhaps millions) of followers, and their circles of friends are also very influential — and they are connected to other celebrities, whose work and messages have a very long reach. Frances Fisher, for example, supports liberal causes and agendas closely related to the Democratic Party. Due to her career, the actress is connected to a group of Hollywood personalities — some already consolidated and others of more recent trajectory, aspiring to be stars that operate in the same logic and in support of the same causes - almost all with "progressive" agendas and antagonistic to the administration of Donald Trump and the political agendas of the American right or far-right.

Among this group, we find people like Susan Sarandon, Jane Fonda, Lily Tomlin, Leonardo DiCaprio, Rosario Dawson, Mark Ruffalo, Matt McGorry, Maya Rose Berko, Kendrick Sampson, Madeline Kelly Merritt, Estefania Rebellon, Max Carver, Shailene Woodley, Patricia Arquette, Margot Kidder, Esai Morales, Alfred Molina, Ed Asner, Danny Glover, Danny DeVito, Viola Davis, Taboo (The Black Eyed Peas), YoNasDa Lonewolf Hill,

\footnotetext{
15 \#BankExit campaign encouraged citizens to withdraw their money from influential banks such as Wells Fargo, Bank of America, Citibank, Chase and HSBC. These actions meant a symbolic punishment against banking institutions that decided to fund the Dakota Access pipeline, a massive infrastructure project that would allegedly damage the environment and predate strategic natural resources in indigenous peoples' lands.

${ }^{16}$ Kane is also related to The People for Bernie Sanders and formed part of the board of the John S. and James L. Knight Foundation in Charlotte, NC.
} 
among others, as well as a list of influential documentary filmmakers such as Josh Fox and Michael Moore. Frances Fisher is also very well connected with allies in media that have widely disseminated platforms among a certain type of audience-identified with progressive causes—such as Democracy Now!, The Young Turks (TYT), Russia Today (RT), The Intercept, $A J+$, Unicorn Riot and others. Finally, these actors maintain very influential friendships in politics — closely linked to the Democratic Party—such as Tulsi Gabbard, Jill Stein, Bernie Sanders, as well as influencers on social justice issues such as Cornel West and Dolores Huerta.

Although this group is directly linked to the organizers and founding members, and performs a mediating work between the messengers and those groups and actors that organize and provide humanitarian support, it is really they, the influencers, who dictate the course of actions, campaigns and social movements. It is through its vast network of followers and contacts that they are able to determine the tone and direction of campaigns nationwide, as well as the direction of political actions related to their movement and ideology. These actors also exert international influence and are close to personalities of great political and economic power inside and outside the United States, who provide financial support to the movement and groups of activists or organizers.

\section{SNA OF NEW ACTIVISM IN THE AMERICAS}

This section applies SNA to the interactions between the 21 actors mentioned above in social networks and to their simultaneous appearance or mention in the media and electronic platforms. These interactions were observed starting in August 2016. The SNA has two main functions or utilities: i) the visualization of the social interactions between actors; and ii) the analysis of the structural design of the network. The connections between the actors (what are known as "nodes", representing either specific individuals, groups or organizations) are shown using lines or links (what are known as "edges"). The links can be either 'directional' or 'non- 
directional'. Directional links are used when the direction of information flows are of research interest. $^{17}$

There were 21 actors/nodes who are apparently related to the border support network (BSN) described above. The links/edges between actors represent the following eight types of interactions (especially through Facebook) ${ }^{18}$ :

1. Person A (or their organization) "mentioned" person B (or their organization) in a post or message sent through the social network.

2. Person $\mathrm{A}^{19}$ (or their organization) invited person $\mathrm{B}$ (or their organization) to participate in an activity organized by A, via the social network.

3. Person A (or their organization) cited or referred to something that person B (or their organization) mentioned in the social network

4. Person A had a "reaction" in social networks (through a 'like' or a similar expressionsuch as a heart or smiley emoji or approval) to the post or message of the person B in the social network.

5. Person A "shared" the Facebook post/message (or other social network) placed by person B or the organization to which this last actor/group of actors is affiliated.

The five links mentioned above are uni-directional $(\mathrm{A} \rightarrow \mathrm{B}$ or $\mathrm{B} \rightarrow \mathrm{A}$, only). The three links presented below (also as input or in-degree degrees) are bi-directional (that is, $\mathrm{A} \rightarrow \mathrm{B}$ and $\mathrm{B} \rightarrow \mathrm{A}$ at the same time).

6. Both people/actors (A and B) participated in the same event (according to information in the media, blogs or any other social network).

7. Both people appeared in the same article or media note. ${ }^{20}$

\footnotetext{
${ }^{17}$ On social network analysis, see Wasserman y Faust (1994) y Borgatti, Everett and Johnson (2018).

18 The majority of the interactions that are considered in the matrix to perform the SNS (Figure) occur in Facebook, which is the preferred media outlet by the BSN members.

${ }^{19}$ When we say "persons," we could also be talking about the organizations to which these persons are affiliated or linked with.

${ }^{20}$ This article could have been shared by one of the actors in the network or by any other group or organization.
} 
8. Both people were mentioned in a post/message (in the social network) of a third person/group/organization.

Figure 3: Weighted Matrix of Actors' Interactions

\begin{tabular}{|c|c|c|c|c|c|c|c|c|c|c|c|c|c|c|c|c|c|c|c|c|c|}
\hline & Mron Dewey & Mark Lane & $\begin{array}{l}\text { Mohamed M. } \\
\text { Elnakilib }\end{array}$ & $\begin{array}{l}\text { Birclie } \\
\text { Gutilerrez }\end{array}$ & $\begin{array}{l}\text { Evan Kout } \\
\text { III }\end{array}$ & " Nucole Ram & nos Prave Queer & veen Und Sarsou & our Alex Mensing & ne Winnie Wone & Doue Mclean & $\begin{array}{l}\text { Frances } \\
\text { Fisher }\end{array}$ & Sav Pont I & $\begin{array}{c}\text { Paoto } \\
\text { Mendora }\end{array}$ & Destrice Kane & $\begin{array}{l}\text { Shane } \\
\text { parmely }\end{array}$ & $\begin{array}{l}\text { Vanessas } \\
\text { Dundoon }\end{array}$ & $\begin{array}{l}\text { Muan } 8 . \\
\text { Mancias }\end{array}$ & ulth Sinctar & $\begin{array}{c}\text { Wrotate } \\
\text { Eesclemen }\end{array}$ & Rob Wilson \\
\hline nowever & $x$ & 1 & 1 & 15 & 43 & 5 & 3 & 5 & 3 & 5 & 30 & 86 & 12 & 3 & 45 & 0 & 35 & 70 & 20 & 30 & 3 \\
\hline trane & 0 & $x$ & 66 & 77 & 6 & 19 & 5 & 20 & 2 & 6 & 5 & 0 & 1 & 13 & 2 & 94 & 3 & 1 & 3 & 6 & 0 \\
\hline thamed $M$. & 0 & 41 & $x$ & 31 & 3 & 2 & 0 & 98 & 1 & 16 & 1 & 0 & 0 & 0 & 0 & 96 & 0 & 0 & 0 & 1 & 0 \\
\hline rile & 32 & 51 & 30 & $x$ & 24 & 20 & 13 & 3 & 7 & 0 & 3 & 1 & 1 & 1 & 0 & 15 & 7 & 2 & 9 & 18 & 1 \\
\hline souke & 43 & 7 & 1 & 31 & $x$ & 2 & 1 & 0 & 6 & 3 & 5 & 7 & 19 & 1 & 5 & 12 & 37 & 57 & 29 & 48 & 2 \\
\hline Ramos & 3 & 31 & 20 & 20 & 3 & $x$ & 12 & 13 & 50 & 1 & 2 & 4 & 3 & 21 & 0 & 12 & 1 & 3 & 1 & 2 & 2 \\
\hline ra Queen & 2 & 10 & 5 & 12 & 1 & 10 & $x$ & 2 & 3 & 0 & 1 & 0 & 0 & 2 & 0 & 0 & 2 & 11 & 2 & 2 & 0 \\
\hline Sarsour & 0 & 9 & 54 & 8 & 0 & 0 & 0 & $x$ & 0 & 54 & 0 & 0 & 0 & 8 & 1 & 7 & 0 & 0 & 0 & 0 & 0 \\
\hline Menaing & 4 & 12 & 6 & 11 & 4 & 97 & 19 & 1 & $x$ & 0 & 1 & 0 & 1 & 8 & 0 & 2 & 3 & 1 & 3 & 3 & 2 \\
\hline ie Wons & 4 & 4 & 42 & 2 & 4 & 1 & 0 & 152 & 0 & $x$ & 3 & 31 & 34 & 1 & 71 & 1 & 1 & 0 & 0 & 10 & 2 \\
\hline aclean & 19 & 0 & 0 & 10 & 6 & 7 & 6 & 10 & 0 & 5 & $x$ & 69 & 40 & 1 & 16 & 0 & 21 & 4 & 0 & 4 & 40 \\
\hline ces & 86 & 0 & 0 & 1 & 11 & 0 & 0 & 4 & 0 & 45 & 71 & $x$ & 57 & 7 & 3 & 1 & 21 & 2 & 0 & 1 & 5 \\
\hline vPonti & 5 & 0 & 0 & 1 & 17 & 0 & 0 & 2 & 0 & 19 & 27 & 78 & $x$ & 0 & 27 & 0 & 13 & 3 & 0 & 4 & 0 \\
\hline & 0 & 9 & 1 & 3 & 0 & 7 & 1 & 8 & 0 & 2 & 0 & 3 & 1 & $x$ & 0 & 4 & 2 & 0 & 0 & 0 & 0 \\
\hline esiree Kane & 64 & 44 & 0 & 15 & 16 & 1 & 0 & 7 & 0 & 49 & 43 & 58 & 63 & 1 & $x$ & 0 & 18 & 16 & 0 & 87 & 11 \\
\hline $\begin{array}{l}\text { Shane } \\
\text { Parmely }\end{array}$ & 1 & 75 & 36 & 24 & 0 & 14 & 1 & 5 & 3 & 1 & 0 & 1 & 0 & 4 & 0 & $x$ & 1 & 0 & 2 & 0 & 0 \\
\hline $\begin{array}{l}\text { Vanessa } \\
\text { Dundon }\end{array}$ & 29 & 1 & 1 & 15 & 23 & 3 & 1 & 7 & 2 & 10 & 18 & 30 & 32 & 2 & 15 & $\cdot$ & $x$ & 71 & 8 & 20 & 3 \\
\hline Juan B. & 55 & 1 & 1 & 2 & 61 & 0 & 1 & 0 & 1 & 0 & 1 & 2 & 4 & 0 & 1 & 0 & 46 & $x$ & 18 & 31 & 1 \\
\hline nthr Sinclatr & 14 & 0 & 1 & 7 & 25 & 2 & 1 & 1 & 3 & 0 & 2 & 0 & 0 & 0 & 0 & 0 & 11 & 15 & $x$ & 18 & 4 \\
\hline mar & 16 & 2 & 2 & 10 & 12 & 0 & 0 & 1 & 0 & 2 & 1 & 4 & 3 & 2 & 2 & 1 & 11 & 3 & 8 & $x$ & 0 \\
\hline Wilson & 13 & 0 & 3 & 3 & 37 & 4 & 3 & 0 & 2 & 0 & 7 & 6 & 1 & 1 & 0 & 0 & 42 & 0 & 39 & 36 & $x$ \\
\hline
\end{tabular}

The intensity of interactions between agents/nodes is summarized in the form of a matrix, as seen in Figure 3. Each cell in the $21 \times 21$ matrix contains the number of uni- and bidirectional interactions between actors ${ }^{21}$. Uni-directional interactions between actor $\mathrm{i}$ and actor $\mathrm{j}$ were recorded in the cell $\mathrm{Cij}$, while bi-directional interactions were counted twice, in cells $\mathrm{Cij}$ and $\mathrm{Cij}$.

The total number of interactions between the 21 actors was 131 . The following two figures show two types of social networks that illustrate the relative importance of the 21 selected actors/nodes, as well as the direction and the magnitude of the interactions between them.

In the network shown in Figure 4, the size of each node represents the total number of actors with which the node is connected (what is known as "unweighted network"). The

\footnotetext{
${ }^{21}$ Each number in the matrix is supported by a copy of the media story or screenshot of the interaction (reaction or emotion) in the social media.
} 
network in this diagram indicates that Birdie Gutierrez (with 20 connections $^{22}$ ) and Vanessa Dundon (18) are the two nodes with the highest number of connections with the other actors; They are closely followed: Wiyaka Eagleman, Doug McLean, Evan K Duke III and Linda Sarsour (all of them with 17 connections). It should be noted that three of the largest nodes (Dundon, Eagleman and Duke) correspond to founding members who participated in Standing Rock and who supported with their physical presence the great migrant caravan that began in October $2018 .^{23}$

\section{Figure 4: SNA of 21 Actors: In-Degree Network / Unweighted}

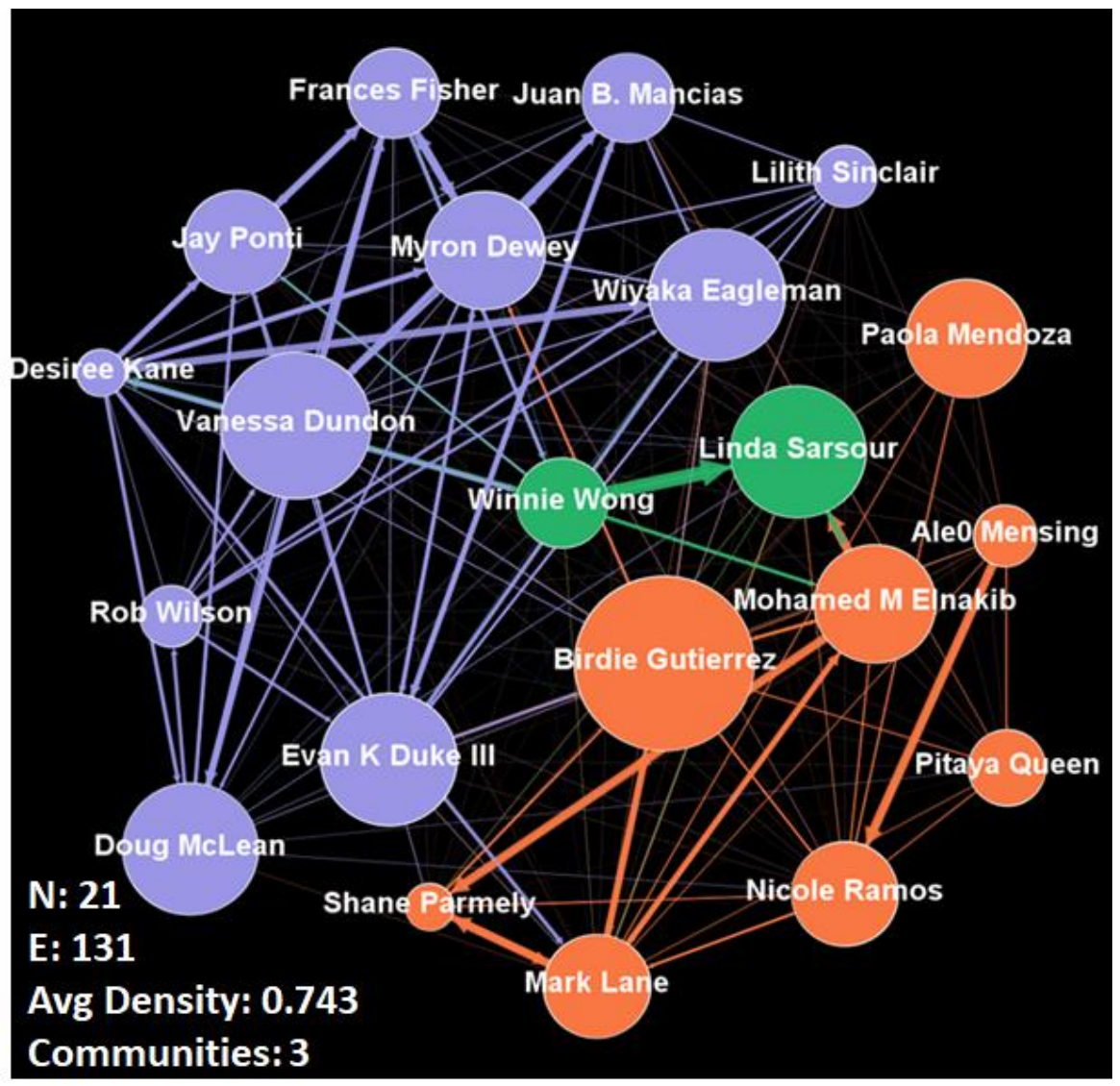

In the network shown in Figure 5, the size of each node represents the relative volume of the interactions (i.e., mentions, in this particular case) that each actor receives from the other

\footnotetext{
${ }^{22}$ This means that Gutierrez is connected with all other actors in the network except for one.

${ }^{23}$ See Gómez-Schempp (2018) for further information on their participation in Mexico supporting the migrant caravan.
} 
actors in the network (what is known as "weighted network"). The largest nodes in the diagram are those of Myron Dewey (390 mentions), Frances Fisher (380 mentions) and Linda Sarsour (339 mentions). They are the three actors who received the highest number of mentions from the other actors. Dewey is a key founding member in Standing Rock who supported the caravan, while Fisher and Sarsour are recognized and influential figures who articulate, from their respective spaces, a progressive agenda with access to large media coverage and financing. It should be noted that Sarsour and Fisher were both present at Standing Rock and had a large influence over the organization of the events.

\section{Figure 5: SNA of 21 Actors: In-Degree Network / Weighted}

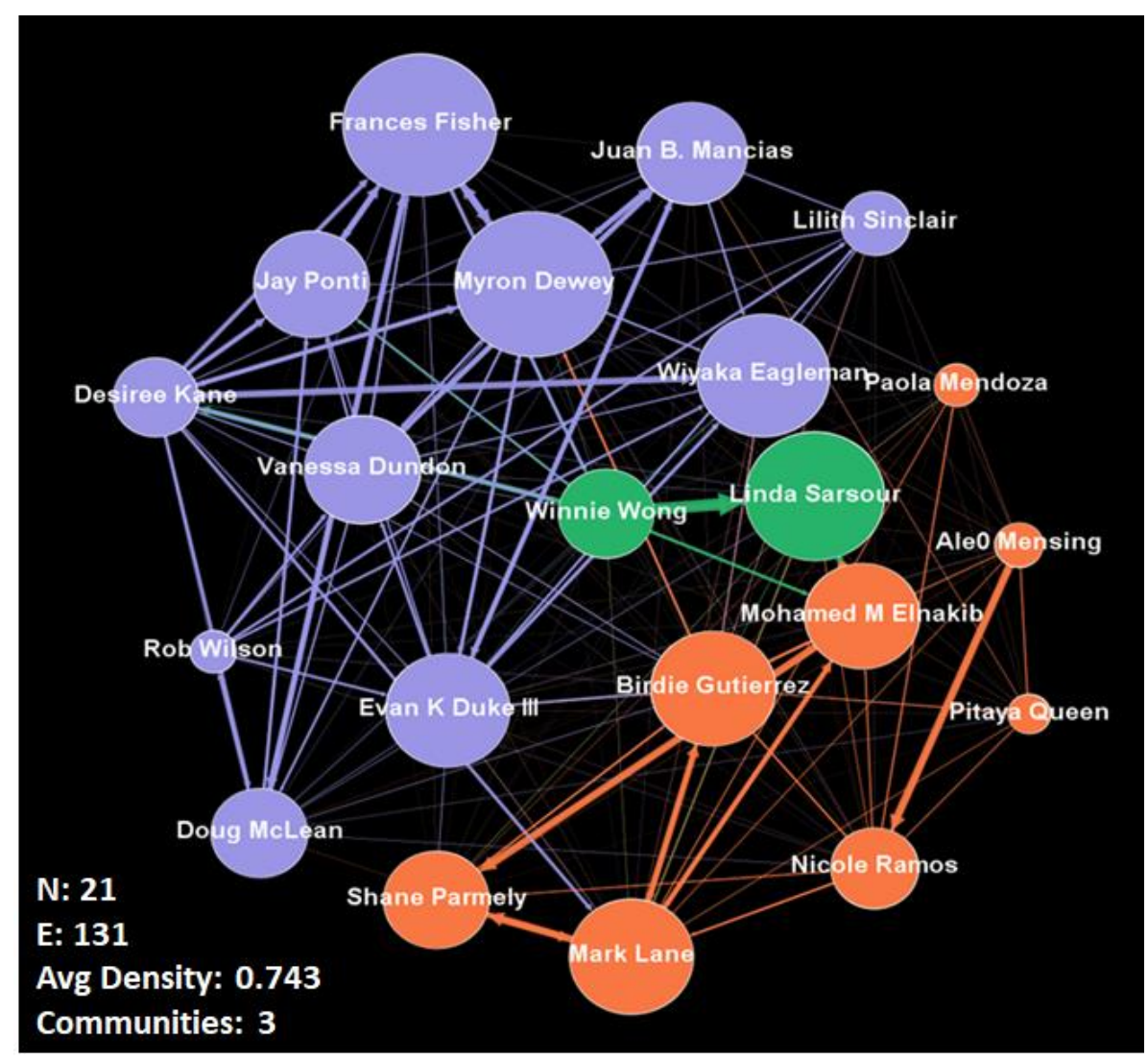

The colors of the two figures (blue, green and orange) show different communities of actors. The actors in the same community tend to be mentioned simultaneously or that refer to each other frequently — forming a kind of grouping. The SNA detected three (3) communities. It should be noted that these three communities do not respond exactly to the four categories 
that we established from the beginning that show the role of the actors within the network. The only community that visibly approaches our classification of actors is the one that is shown in orange and includes actors seeking financing to do humanitarian work.

It should be noted that the three groups formed as a result of SNA reflect the interactions between our sample of 21 actors only. This methodology does not tell us anything about the content of the interactions or about their nature. In general, we can interpret the three communities resulting from the SNA as follows: one is formed by the actors who participated in Standing Rock in different roles (the blue community); another one of those who participated in the accompaniment or support to the migrant caravans (orange community); and the last is formed by influential personalities that advocate for large progressive movements in the United States (green). The average density of the network, which is a measure of the level of connectivity within the system, was 0.743 . This means that the network system is relatively dense, with a possibility of about $75 \%$ of any pair of nodes in the network being connected.

\section{CONCLUSIONS}

The utilization of SNA to analyze two social movements of apparently distinct nature and different motivations shows a very close connection and communication between their organizers, contacts and other key actors. Moreover, the present study allows us to think more deeply about the type of actors who participated in these two episodes of social mobilization, its objectives and main strategies. Ostensibly, these two phenomena are not isolated and are not essentially "organic"; in other words, they do not seem to be completely spontaneous. The analysis of key actors in these movements and their strategies, illustrates their politicalelectoral motivations that seem to motivate some of their actions. Notwithstanding the fact that the two movements are distinct in essence, they have been backed up and organized by similar actors that support-or have direct presence in-other more recent episodes of social 
mobilizations (in Hawaii and Puerto Rico, for example, and other resistance movements against current U.S. border security and migration policy).

These movements are considered progressive and many of them are focused on environmental protection or humanitarian work (mainly with migrants and refugees). Nonetheless, and taking into account the sophisticated organization of such movements, the not very transparent sources of funding that many of them receive and their international reach, it is possible to believe that the ultimate goal of their organizers is actually of political-electoral nature, and could be even geopolitical. The SNA presented here gives us a preliminary idea of the composition of a network of activists that apparently uses the idea of 'resistance', communication media and show business personalities (or celebrities) in order to advance agendas that are not related to their original goals and mission.

Through the present research we could verify the direct relationship that exists or existed between activists that were key in the organizations or mobilization of migrant caravans and U.S. politicians, international communication media outlets, NGOs, radical groups or antisystem movements, and the show business or entertainment industry. This study also identified and analyzed some of the details of these interactions and the profiles of key actors that participated in the network. The connections with the Standing Rock protests is evident. The analysis of the interactions in the social media supports this assertion. The results of the SNA performed for this project showed a level of density of $74 \%$, which reflects a close connection between the 21 selected actors.

The actors analyzed here are related to other movements such as Occupy Wall Street, the Women's March, the anti-Israeli movement Boycott, Divestment and Sanctions (BDS) and campaigns of important political leaders in the United States. At the same time, some have interacted and communicated their messages through media platforms administered in other continents (Yaworsky, et al. 2020). These preliminary study shows a complex network of 
political-electoral (and maybe economic) interests, supported by international communication media that could, under certain circumstances, affect the geopolitics of hemispheric security.

Occasionally, it has been hypothesized that there is a sort of collusion between activists or 'professional' organizers of social movements (professional activists) and other political, economic (and even geopolitical) interests more difficult to identify. The relevant dynamics are not quite clear and there is still a lot to investigate with regards to this topic. It is quite interesting to notice that recent social mobilizations and mass migrations, apart from showing an organic or spontaneous component driven by genuine necessities by vulnerable populations or communicates at risk, seem to respond additionally to interests which could have a transnational base. Such an origin might be located in the more developed world, and particularly in the United States.

The so-called "Prophecy of the Eagle and the Condor" that is utilized by activists who participated in Standing Rock to recruit volunteers for the Border Support Network, and who now to support migrant caravans and other transcontinental migrations coming from the south of the continent-illustrates new forms of mobilization that justify a leadership coming from more developed countries. Finally, it is worth noting the fundamental role that the so-called 'influencers' and celebrities play to recruit adepts, and to further and justify new mobilizations through formal communication media and other social media platforms-which have their headquarters in the most power nations of the world. 


\section{REFERENCES}

Álvarez, Priscilla. 2018. "Why migrant caravans keep forming?” The Atlantic. October 25.

Borgatti, Stephen P., Martin G. Everett and Jeffrey C. Johnson. 2018. Analyzing Social Networks (second edition). Thousand Oaks, CA: SAGE.

Brewer, Graham Lee. 2018. "The squandered funds raised around Standing Rock. What we learned about accountability from a nine-month investigation into \#NoDAPL." High Country News, April 13. https://www.hen.org/articles/indian-country-news-thesquandered-funds-of-standing-rock.

Buechler, Steven M. 1995. "New social movement theories". The Sociological Quarterly 36(3): 441-464.

Carlsen, Laura- 2018. "Why the refugee caravan is so big-and what we need to do about It?" The Nation, November 2.

Correa-Cabrera, Guadalupe and Alan Bersin. 2018. "Migrant activists and human smugglers collaborated at the southern border: Innocents lost". The Hill, December 29. https://thehill.com/opinion/immigration/423181-migrant-activists-and-humansmugglers-collaborated-innocents-lost.

Das, Kousik, Sovan Samanta and Madhumangal Pal. 2018. "Study on centrality measures in social networks: A survey”. Social Network Analysis and Mining 8(1): 13.

Estes, Nick. 2019. Our History Is the Future: Standing Rock Versus the Dakota Access Pipeline, and the Long Tradition of Indigenous Resistance. New York, NY: Verso.

Estes, Nick and Jaskiran Dhillon, eds. 2019. Standing with Standing Rock: Voices from the \#NoDAPL Movement (Indigenous Americas). Minneapolis, MN: University of Minnesota Press.

Felter, Claire y Zachary Laub. 2019. "Who secures the U.S. border?" Council of Foreign Relations, February 15. https://www.cfr.org/backgrounder/us-mexico-border-woes.

Funes, Yessenia. 2018. "What happened to the \$8 million people raised for Standing Rock?" Gizmodo, April 13. https://earther.gizmodo.com/what-happened-to-the-8-millionpeople-raised-for-stand-1825247756.

Gómez-Schempp, Cindy Azucena. 2018. "Standing Rock caravan infiltrators". Kpppfm.com, December 11. http://kpppfm.com/articles/standing-rock-caravan-infiltrators/.

Hallock, Jeffrey, Ariel G. Ruiz Soto and Michael Fix. 2018. "In search of safety, growing numbers of women flee Central America". Migration Policy Institute, May 30. https://www.migrationpolicy.org/article/search-safety-growing-numbers-women-fleecentral-america.

Jenkins, J. Craig. 1983. "Resource mobilization theory and the study of social movements". Annual Review of Sociology 9(1), 527-53. 
Linthicum, Kate. 2018. "Pueblo Sin Fronteras uses caravans to shine light on the plight of migrants—but has that backfired?" Los Angeles Times, December 6.

McAdam, Doug, John D. McCarthy and Mayer N. Zald, eds. 1996. Comparative Perspectives on Social Movements: Political Opportunities, Mobilizing Structures, and Cultural Framings. New York, NY: Cambridge University Press.

Sieff, Kevin. 2018. "Why travel with the caravan? To avoid one of the world's most dangerous smuggling routes". New York Times, October 25.

Slack, Jeremy and Howard Campbell. 2016. "On Narco-coyotaje: Illicit Regimes and their Impacts on the U. S.-Mexico Border". Antipode 48(5): 1380-99.

Solalinde, Alejandro and Guadalupe Correa-Cabrera. 2019. "Caravanizando la migración: Una perspectiva desde México”. Proceso 2217: 62-3.

Tarrow, Sidney. 1998. Power in Movement: Social Movements and Contentious Politics (second edition). New York, NY: Cambridge University Press.

United Nations Office on Drugs and Crime (UNODC). 2010. "Organized crime involvement in trafficking in persons and smuggling of migrants" (report). New York, NY: UNODC.

Vogt, Wendy A. 2013. "Crossing Mexico: Structural violence and the commodification of undocumented Central American migrants". American Ethnologist 40(4): 764-80.

Wasserman, Stanley and Katherine Faust. 1994. Social Network Analysis: Methods and Applications. New York, NY: Cambridge University Press.

Yaworsky, William, et al. 2020. "The Eagle, the Condor, and Exodus: New Directions in Political Theater and Border Spectacle" (unpublished manuscript). 